\title{
Implementation of Total Quality Management in Higher Education (A Case of State University of Gorontalo, Indonesia)
}

\author{
Ansar \\ Faculty of Education, Universitas Negeri Gorontalo \\ Corresponding e-mail: ansar bone@yahoo.co.id
}

\begin{abstract}
The overall purpose of this study was to investigate the application of TQM principlesto improve the quality of academic servicesat State University of Gorontalo.This purpose is conducted towards an evaluation and assessment of the current quality work at State University of Gorontalo, which determined in three phase, namely: precondition phase; implementation phase and monitoring/evaluation phase. This study employed quantitative approach with descriptive methods. The sample consisted of 50 faculty members from nine colleges/faculties in State University of Gorontalo. The findings of this study indicated that the applications of the TQM principles in precondition and implementation phase are in moderate category. However in monitoring/evaluation phase the TQM principles were poorly implemented. To be successful in implementing of Total Quality Management (TQM) at the State University of Gorontalo, this research suggested the following: (1) There are need to increase the commitment of top management in term of quality, quality awareness, leadership quality, and the quality culture through the dissemination of quality, workshop quality, and quality program, (2) The need to set up an institutional quality document (quality policy, quality standards, quality manual, standard procedure operational), (3) Involve all faculty members actively in supporting the implementation of TQM, and (4) Creating Quality Improvement (QI) team or Quality Evaluation Committee (QEC).In conclusion, a complete framework of Total Quality Management principles is developed, which can facilitate State University of Gorontalo to improve the quality of its institution.
\end{abstract}

Keywords: Total quality management, implementation, quality, and academic services

\section{INTRODUCTION}

Quality improvement is the main priority of Universitas Negeri Gorontalo reflected in its vision, becoming a leading university in developing regional potential based culture and innovation in South East Asian. In the Merah Maron Universitas Negeri Gorontalo [25], book entitled "The Acceleration Pilllars 2015 - 2018", it is firmly confirmed that by 2025 Universitas Negeri Gorontalo will get inaugurated as a leading university in the regional potential based culture and innovation development, the premiere in innovations on education, teaching, research, and community services as well as the role model, the pioneer and the inspiration on higher education improvement for other higher education institutions.

The vision of Universitas Negeri Gorontalo has become not only a challenge but also a moral responsibility to all the university's academics. The challenge is to improve academic quality that is currently ranked at the low level. The study program accreditation results show that around $65 \%$ of the study programs got $\mathrm{C}$ score, $35 \% \mathrm{~B}$, and none $\mathrm{A}$.
This indicates that quality improvement management has not been successfully implemented. Therefore proper solution to plan, implement, and evaluate proper quality improvement strategy is required [3].

Total Quality Management (TQM) implementation in industrial sector has shown outstanding results. A question remains whether it can also be implemented in education sector, particularly higher education institutions [12].

The results of observation and discussion with some Universitas Negeri Gorontalo officials indicate that the university has implemented TQM concepts such as the establishment of Quality Assurance Center, accreditation program, and quality standard establishment [2]. . However, these have not yet shown maximum impact on quality improvement. Therefore, there needs to be a research study on TQM implementation in improving academic quality at the university [7].

This research reviews TQM implementation in academic services at Universitas Negeri Gorontalo throughout the stages of initial condition, planning, implementation, and evaluation. 


\section{METHOD}

This research applies quantitative approach with descriptive method reinforced by qualitative analysis. This research is carried out within 2 (two) stages in the period of 6 (six) months. At the first stage, quantitative approach of descriptive type is applied. The Stage I results in the description of TQM implementation stages at academic services of Universitas Negeri Gorontalo. The findings of the first stage research are reviewed at stage II research by applying qualitative approach. The findings of the stage II research enhance the Stage I findings to elaborate various critical, successful elements. The synergy of Stage I and Stage II generates comprehensive findings.

This research is carried out at the academic services of Universitas Negeri Gorontalo, i.e. Academic Administration Bureau at the university level, the Education and Teaching Unit at the faculty level, and Academic Services at study program level. The respondent of this study are staff, lecturers, and leaders engaged in academic services at university, faculty, and study program levels. The research respondents and informants are purposively selected based on the data as required and the information as needed.

\section{RESEARCH FINDINGS AND DISCUSSIONS}

The research findings on TQM implementation at academic services of Universitas Negeri Gorontalo are presented in the following table:

At the initial condition stage, TQM implementation is still at middle category. This means that initially TQM implementation has not fully supported Universitas Negeri Gorontalo to develop excellent quality that is in line with the vision "becoming a leading university in developing regional potential based innovation and culture in South East Asia" [25].

The empirical review shows that in general lecturers and staff have not yet understood Universitas Negeri Gorontalo's vision, therefore, theoretically, they do not yet work by the vision. The understanding of the vision and the effort of socializing it as described in the university accreditation documents are very contradictive. It is described in the documents that the vision socialization process is done through the university website and various internal and external meetings. The university printed media is active socializing the vision through handbooks or academic guidelines, leaflets, brochures, and banners when university events are being held. The socialization is also done intensively in different events, e.g. meetings, student admission and new student orientation programs. The university leaders also conduct ongoing socialization in different internal activities, e.g. faculty and study program meetings, and external activities, e.g. electronic media and printed media such as billboards to be accessible to a wider community on campus or off campus [2].

Theoretically the lecturers' understanding of the vision is closely related with the provided socialization on the vision. The understanding of the lecturers and all the university's stakeholders determines the direction towards quality improvement [22], [20].

It is still a challenge to fulfill the criteria towards becoming an excellent university that requires total improvement. Some initial conditions are basic assets in developing excellent quality, e.g. quality awareness, quality commitment, quality culture, and quality leadership. The research findings show that the initial conditions are still classified in middle category. On the other hand, it requires excellent initial conditions to develop excellent quality. The challenge is to determine the initial conditions to be basic, excellent assets for

Table 1. Research summary of TQM implementation:.

\begin{tabular}{|c|l|c|c|}
\hline No. & Variable & Percentage (\%) & Category \\
\hline 1 & Initial Condition (Preparation) & 64,60 & Middle \\
2 & Quality Planning & 63,09 & Middle \\
3 & Implementation & 76,36 & High \\
4 & Evaluation & 46.20 & Low \\
\hline & Average & 62,56 & Middle \\
\hline
\end{tabular}


developing excellent quality. This is where excellent leaders are required to transform TQM in all organizational units [11].

Quality should be top-down built. Therefore, Universitas Negeri Gorontalo Rector as the top leader should have high commitment towards quality and be capable of mobilizing all main components, particularly lecturers and staff in achieving the set quality targets. The importance of commitment towards quality development has been elaborated in some literatures, pointing out the failure in quality implementation at an organization caused by lack of commitment of the leaders. Sallis state that $80 \%$ of TQM implementation failure is caused by the lack of commitment of leaders[21]. Usually non-TQM organizational leaders spend $30 \%$ of their time encountering system failure, complaints, and problem-solving. On the other hand, managers implementing TQM do not have sufficient time and therefore use the $30 \%$ time to lead, plan for future, develop new ideas, and work closely with the customers [3].

The theoretical review by Crosby, indicates these conditioned steps on quality program, first being management commitment, second quality improvement team, third quality measurement, fourth quality cost, fifth quality awareness, sixth corrective action, seventh zero defects planning, eighth supervisor training, ninth zero defects implementation, tenth goal setting, and eleventh error elimination [21], [7].

Empirically, initial conditions of TQM implementation have not been ideal. Some aspects are still categorized middle and low even though some others have been categorized high and very high, e.g. the commitment of the Rector as the top management. This is indicated in the verbal expressions and encouragement given by the Rector to all the university's elements to always improve quality, establish acceleration teams, and improve study program and institution accreditation. Hard work of all elements has resulted in the university obtaining B score in the institution accreditation. The Rector has even expected for the university to be ISO certified with international quality certification in 2017. Obtaining ISO certification requires hard work and collaboration of all existing potentials for serious quality improvement. However, some leaders have not yet showed maximum real actions on quality improvement, e.g. unavailable quality programs and lack of attention towards quality assurance cluster at faculty level.

The leaders' seriousness towards quality assurance is reflected in the Acceleration Pillar Book
2015 - 2018. The book is developed to be the reference for all the academics and the leaders at Universitas Negeri Gorontalo. Acceleration is a strategy to accelerate improvement at the university in the 21 st century. These are elaborated in the book: (1) quality assurance, (2) soft skills and entrepreneurship, (3) environment for green campus, and (4) partnership and innovation [25].

The empirical review of establishing quality improvement team at Universitas Negeri Gorontalo is done by the Quality Assurance Working Unit. At institution level, quality assurance is managed by Academic Quality Assurance Board that is responsible to report to the Rector. At faculty and post-graduate level, it is managed by Faculty and Study Program Quality Assurance Unit that is responsible to report to the Director/Dean [2].

The Board and the Unit have been officially legit imitated by the Rector Decree Number $1224 / \mathrm{UN} 47 / \mathrm{PM} / 2012$ on the institutional establishment, outlining the main task and function of quality assurance units at university, faculty, study program, and postgraduate levels. The units are responsible to disseminate quality documents, monitor implementation quality of teaching and learning and teaching and learning materials and their supporting materials, e.g. laboratory and education evaluation.

The empirical review shows that the established quality assurance units have not properly functioned as expected. The Board, which is expected to prepare standardized quality documents and get them disseminated to all academic services units, has not effectively functioned [19]. However, there are eighty-eight university accreditation documents. The documents are not found in the working units, even the lecturers and staff are not aware of their existence. They should be distributed to the units. As the result, the delivered activities do not refer to the documents, e.g. proposal seminar exam, seminar result exam, and study program exams have each their own implementation procedures [3].

Leadership is a determining element in TQM implementation, i.e. quality-oriented leadership. Ros, states that quality leadership has these characteristics: (1) visible, committed, and knowledgeable, (2) missionary enthusiasm, (3) aggressive target, (4) strong driver in communicating organizational values and getting in contact with the customers [24]. On the other hand, Juran (Ciptono and Diana, 2003) states that qualityoriented leadership covers 3 (three) managerial 
function, i.e. ongoing quality planning, monitoring, and improvement [25].

The empirical review shows that not all leaders at Universitas Negeri Gorontalo have quality leadership characteristics. As the result, sometimes innovative ideas of the Rector cannot be elaborated and implemented at faculty and study program levels [3].

Quality system planning is started from the vision and mission documents. These documents are used as the references when developing strategic plans, quality policies, quality standards, academic requirements, standard operating procedures, and action plans [17], [18].

Implementing higher education quality management principles is very important to ensure ongoing quality improvement. An institution should develop quality system in the form of written quality manual as the reference for everyone involved to achieve the set quality performance standards. Quality management system implementation should be regularly audited to get inputs for management review towards system improvement [16].

Consistent implementation of quality management system will give benefits and success to all related stakeholders in the institution. Therefore it is important to ensure that the quality management principles are in place. Deming identifies these 14 (fourteen) principles: (1) attempt to improve product and service to be competitive, (2) adapt new philosophy, (3) avoid dependency upon public inspection to create quality, (4) complete practice and respect business with price, (5) consistently enhance product and service system, (6) institutionalize professional training, (7) institutionalize leadership, (8) get rid of fear, (9) elaborate issues across departments, (10) omit slogans, pressures, and targets, and improve productivity without adding more workload, (11) omit working standards that use numerical quotes, (12) omit issues that can take away the pride of the staff on their expertise, (13) institutionalize various education programs that increase work enthusiasm and quality improvement, (14) designate one staff in the working team to do the transformation [21].

Quality management principles should be cultivated in all university personnel so that they can use them as the references when performing actions towards developing and implementing consistent, sustainable quality management system. Quality management system cannot give maximum benefits without the principles [10].

At this stage, quality measurement process is to ensure the achievement of the set quality targets.
The empirical review shows that Universitas Negeri Gorontalo has established quality assurance units, i.e. Academic Quality Assurance Institution at university level and Faculty Quality Assurance Cluster at faculty and study program levels. These units are responsible to monitor internal academic quality at the university. Therefore, they are empowered to be capable of undertaking their responsibilities. Currently they are only capable of preparing and assisting administration process during institution and study program accreditation and are not yet capable to perform TQM. The challenge in the accreditation process is not on how to provide accreditation documents and selfevaluation but what to be written on them [26].

Quality acknowledgement by external party is required since Universitas Negeri Gorontalo is part of the community. Accreditation program hosted by independent institution for higher education institution is carried out by the national accreditation board for higher education (BAN-PT). The acknowledgement is required to assure minimum standards are met, leading towards getting the graduates obtain these qualifications: (a) have competences that are in line with the needs of the community; (b) pursue to a higher education or specialization level (c) operate professional practice. These competencies will help the graduates get accepted in the working field [1].

\section{CONCLUSIONS}

TQM implementation in academic services at Universitas Negeri Gorontalo can be summarized in these points: (1) the initial stage (preparation) is categorized at middle level; quality awareness, quality commitment, quality leadership, and quality culture are all at middle level; (2) the planning stage is at middle level; environment assessment, quality documents, quality standards, and training indicators are all at middle level; (3) the implementation stage is categorized at high level; academic quality is at middle level, whereas internal audit and improvement indicators are both at high level; (4) the evaluation stage is categorized at low level..

\section{RECOMMENDATIONS}

These are the recommendations for successful implementation of TQM at Universitas Negeri Gorontalo: (1) there needs to be quality improvement, commitment, awareness, leadership, and culture through quality socialization, 
symposium, and program; (2) quality document development and finalization (quality policy, standard, manual, and SOP); (3) education and training for staff and lecturers for capacity building; (4) establishment of professional quality team.

\section{REFERENCES}

[1] Alzhrani, K.M,. Alotibie, B.A., Abdulaziz, A. "Total Quality Management in Saudi Higher Arabia Education". International Journal of Computer Application. Volume 135-No.4, p 6 $-12,2016$

[2] Ansar "Kajian Sekolah Efektif dalam Prespektif Manajemen Mutu Terpadu Pada SMP Negeri di Kabupaten Pohuwato.Gorontalo “: UNG. 2007

[3] Ansar dan Arifin. "Budaya Mutu PerguruanTinggi studi kasus pada Universitas Negeri Gorontalo.Gorontalo “. UNG, 2014

[4] Boaden, R. J., \& Dale, B. G. "Teamwork in services: quality circles by another name". International Journal of Service Industry Management, 4 (1), 5-24. 1992

[5] Brown, R. "Quality Assurance in Higher Education The UK Exprience Since 1992". London :RoutledgeFalmer. 2004

[6] Burnham, J.W. "Managing Quality in School". London: Prentice Hall. 1997

[7] Cheng, Y.C., and Tam, W.M. "Multi-Models of Quality in Education, Quality Assurance in Education “, Vol 5 (1), pp 22-31. 1997

[8] Creech, B. "Lima Pilar (Manajemen Mutu Terpadu) TQM'.Jakarta : Binarupa Aksara. 1996

[9] Hardjosoedarmo, S. "Dasar-Dasar Total Quality Management". Yogyakarta :Andi. 1996

[10] Harvey, L., \& Green, D. "Defining Quality, Assessment and Evaluation in Higher Education," 18 (1), 9-34. 1993

[11] Juran,J.M., Godfrey, A.B. “Jurans Quality “. Handbook. New York: McGraw-Hill. 1999

[12][Kanji, G.K., and Thambi, A ."Total Quality Management in UK Higher Institutions, Total Quality Management, Vol 10 [1], pp 129-153. 1999.

[13] Katiliute, E., Neverauskas, B. "Development of Quality Culture in The Universities".Journal Economics \& Management ISSN 1822-6515. 2009

[14]Kolter, P. "Manajemen Pemasaran, Analisis Perencanaan dan Pengendalian". Jakarta : Erlangga. 2000.
[15] Morgan, C., Murgatroyd.(1999). Total Quality Management in Public Sector. BuckinghamPhiladelpia : Open University Press.

[16] Morgan,C., \& Murgatroyd,S. "Total Quality Management in The Public Sector. An International Perspective". Open University Press. Buckingham- Philadelphia. 1999

[17]Nasution, M.N. "Manajemen MutuTerpadu (Total Quality Management". Jakarta :Ghalia Indonesia. 2001

[18] Prawirosentono, S. "Filosofi Baru Tentang Manajemen Mutu Terpadu (Total Quality Management) Abad 21".Jakarta :Bumi Aksara. 2004.

[19] Rowley, J."A new lecturer's simple guide to quality issues in higher education". International Journal of Education Management, 9(1), 1995, 24-27. 1995

[20] Sagala,S. "Manajemen Stratejik dalam Peningkatan Mutu Pendidikan".Bandung :Alfabeta.2011.

[21] Sallis, E. "Total Quality Management in Education". Kogan Page Limited. London.1996.

[22] Salusu, J. "Pengambilan Keputusan Stratejik." Jakarta :Grasindo. 1996.

[23] Tjiptono, F. “ Prinsip-Prinsip Total Quality Service.". Yogyakarta :Andi. 2005

[24]Tjiptono, F., Diana, A. "Total Quality Management". Yogyakarta :Andi. 2003

[25]UNG. "Pilar-Pilar Akselerasi 2015-2018". UNG. 2015

[26] Vuksic, V.B., Bach, M.P., Pupek,K.T. "Process Performance Management in Higher Education". International Journal of Engineering Business Management, 6:111. 2014. 